\title{
Sublethal Effects of Indigenous Plant Extracts on the Biochemical Composition of Midgut of Carpenter ant, Camponotus compressus F. (Hymenoptera : Formicidae)
}

\author{
Seema. G. Kadu \\ Department of Zoology, S.S.E.S. Amt’s, Shivaji Science College, India
}

Received June 11, 2020; Revised October 8, 2020; Accepted January 23, 2021

\section{Cite This Paper in the following Citation Styles}

(a): [1] Seema. G. Kadu , "Sublethal Effects of Indigenous Plant Extracts on the Biochemical Composition of Midgut of Carpenter ant, Camponotus compressus F. (Hymenoptera : Formicidae)," Advances in Zoology and Botany, Vol. 9, No. 2, pp. 51 - 59, 2021. DOI: 10.13189/azb.2021.090203.

(b): Seema. G. Kadu (2021). Sublethal Effects of Indigenous Plant Extracts on the Biochemical Composition of Midgut of Carpenter ant, Camponotus compressus F. (Hymenoptera : Formicidae). Advances in Zoology and Botany, 9(2), 52 - 59. DOI: 10.13189/azb.2021.090203.

Copyright $@ 2021$ by authors, all rights reserved. Authors agree that this article remains permanently open access under the terms of the Creative Commons Attribution License 4.0 International License

\begin{abstract}
The sublethal effects of methanolic leaf extracts of some indigenous plant, Azadirachta indica (Neem), Ipomoea carnea (Beshram), Vitex negundo (Nirgudi), Tridax procumbens (Kambarmodi) and Pongamia glabra (Karanj) studied to determine the biochemical and histopathological assay of midgut of household insect pest the carpenter ant, Camponotus compressus $F$. The methanolic leaf extract of Ipomoea carnea and other plants induced sublethal cyto-morphological changes disturbing the biochemical composition of the midgut of the carpenter ant. During the treatment of formulations, 5\%, 10\%, $15 \%$ and $20 \%$ methanolic leaf extracts against the group of carpenter ants demonstrate maximum percentage mortality. After the interval of 24, 48 and 72 hours of the treatment the biochemical constituents such as total proteins, carbohydrates and lipids were significantly reduced in concentrations. The biochemical studies and ultra structural changes in the midgut were observed significant variation in biochemical composition with greatly elongated, vacuolated columnar cells and reduce diameter of nucleus. The study on application of the $20 \%$ methanolic leaf extracts of Ipomoea carnea followed by other plants suggested the significant sub-lethal effects on the digestion, absorption and bimolecular metabolism in the midgut due to the action of toxicant present in the leaf extracts. The present study evaluates the physiological and biochemical changes induced by the application of natural organic
\end{abstract}

herbal formulations prepared from some easily available indigenous plants to control household insect pests.

Keywords Azadirachta indica, Ipomoea carnea, Tridax procumbens, Vitex negundo, Pongamia glabra, Camponotus compressus, Sublethal, Biochemical

\section{Introduction}

The black carpenter ant, Camponotus compressus is an ecologically diverged, dominant polygynous, cosmopolitan found in the tropical and temperate region in India. Due to high species richness and intraspecific, geographical variation these ants generally adapted different habitats playing a dominant aggressive territorial role as household pests and share their nest with other nuisance species like wasps and termites $[17,28]$. The heavy usage of pesticides created a great concern on environment especially in case of household control of pests leftovers the residues which further causes health hazards to humans. These residues bio-accumulated discharging in milk, cattle drinking water, fodder and feed collected from cattle colony [23]. So to control the population of such insect pest some indigenous plant extracts containing ovicidal, repellent, anti-feedant, sterilization and toxic compounds are used $[2,20,13]$. The 
effect of alkaloids and toxic compounds isolated from the leaves, flowers and seeds of the plants, inhibit the carbohydrate, lipid and protein metabolism in certain insect pests [25,29,11,22]. Some plant based insecticide used as the fumigants studied as directly effects on the respiratory tracts of active stages of insect pests [4,32]. There has been numerous research studies conducted at laboratory level on plant products against the household insect pests. Besides toxicity tests, attention has been focused to elucidate their mode of action on insects $[33,9,14,15]$. The purpose of this study was to evaluate the sub-lethal dose and toxicity of the locally available plant extracts to control the adult carpenter ant, Camponotus compressus.

\section{Materials and Methods}

\subsection{Preparation of Methanol Extract}

The fresh tender leaves of the five plants, Azadirachta indica (Neem), Ipomoea carnea (Beshram/sadafuli), Vitex negundo (Nirgudi), Tridax procumbens (Kambarmodi) and Pongamia glabra (Karanj) were cut and chopped in to small pieces and dried in the shade. The $5 \mathrm{mg}$ dried coarse powder of each plant were packed and processed in a Soxhlet Apparatus using $100 \mathrm{ml}$ methanol as the stock solvent. The extracted methanolic leaves extract powder was dissolved in methanol to prepare the 5\%, 10\%, $15 \%$, and $20 \%$ working formulations for spraying as stomach poison under the Potter's Tower. To check the lethal concentrations and percent mortality of adult stages as experimental set [Number of ants $(\mathrm{N})=30$ ] was compared with control set $(\mathrm{N}=30$; treated with distilled water) and Boric powder (1\% Aqueous formulation of conventional synthetic insecticide, as check) (Table-1).

After the Probit analysis for determination of lethal concentration, effects of the $20 \%$ methanol leaf extracts studied for the biochemical estimations and histology of midgut in carpenter ant. The sets of $(\mathrm{N}=10)$ adult stages of ants were again exposed and treated with $20 \%$ methanol leaf extracts of all the plants as the experimental (Exp.) set comparing with control set at the interval of 24, 48 and 72 hours under optimum laboratory conditions.

\subsection{Biochemical Estimations}

After the treatment of $20 \%$ methanol leaf extracts of all the plants the alimentary canal of adult worker carpenter ants was dissected in the Ringer solution under the Stereoscopic Binocular microscope. The midgut was removed from the alimentary canal after each interval of 24, 48, and 72 hour of treatment. The midgut was homogenized for estimation of total protein [18] total carbohydrate [7] and total lipid [8].

\subsection{Histochemical Preparations}

The 20\% methanol leaf extracts of Ipomoea carnea shows reducing biochemical compositions. So to study the histochemical changes in the midgut of carpenter ant after the application of $20 \%$ methanolic leaf extracts of Ipomoea carnea the midgut was dissected and fixed in Bouin's fixative, after each interval of 24, 48 and 72 hours. Fixed tissues were dehydrated in alcohol grades; $70 \%$, $90 \%, 100 \%$ while cleared in xylene and embedded in paraffin wax at $55-56^{\circ} \mathrm{C}$. To study the cellular alterations in midgut structure of carpenter ant the histological slide prepared performing $\mathrm{H}-\mathrm{E}$ staining technique [12]. All the data obtained were generated in triplicates and analyzed using mean, standard error and one-way (one factor) analysis.

\section{Result and Conclusion}

The present study based on application of methanolic leaf extracts of five different plants treated as the potent insecticide against the household pest, carpenter ant, Camponotus compressus. The treatment of these leaf extracts applied in viz., 5\%, 10\%, $15 \%$, and 20\% formulations at the interval of 24, 48 and 72 hours. The exposed groups of carpenter ant divided into two chambers such as Experimental and Control set. The treatment of the $20 \%$ methanolic leaf extracts indicated maximum lethal effects and percent mortality only after the interval of 72 hours against the adult stage of the carpenter ant as compared to synthetic insecticides. The greenhouse trials revealed that the $20 \%$ methanol leaf extracts may acts as the stomach poisons with higher repellent activity showing non-target toxicity at highest mortality rate of adult carpenter ants (Table-1). 
Table 1. Effect of Methanol Leaf Extracts of different plants on percent mortality of the carpenter ant, Camponotus compressus after 72 hours

\begin{tabular}{|c|c|c|c|c|c|}
\hline \multirow{2}{*}{ S. No. } & \multirow{2}{*}{ Leaves Extract of Plants } & \multicolumn{4}{|c|}{ Percentage Mortality/ hour } \\
\cline { 3 - 6 } & & $5 \%$ & $10 \%$ & $15 \%$ & $20 \%$ \\
\hline 1 & Pongamia glabra & $5.92 \pm 0.72$ & $7.96 \pm 0.88$ & $10.41 \pm 2.32$ & $65.34 \pm 2.41$ \\
\hline 2 & Tridax procumbens & $6.22 \pm 1.12$ & $9.27 \pm 1.32$ & $13.34 \pm 3.84$ & $68.56 \pm 7.83$ \\
\hline 3 & Azadirachta indica & $12.55 \pm 1.62$ & $14.67 \pm 2.44$ & $28.55 \pm 5.75$ & $72.38 \pm 6.48$ \\
\hline 4 & Vitex negundo & $21.44 \pm 3.93$ & $26.56 \pm 3.35$ & $47.32 \pm 6.26$ & $85.58 \pm 10.75$ \\
\hline 5 & Ipomoea carnea & $22.52 \pm 4.35$ & $32.55 \pm 5.24$ & $50.51 \pm 8.28$ & $92.36 \pm 12.82$ \\
\hline 6 & $\begin{array}{c}\text { Check-I / } \\
\text { Boric powder }\end{array}$ & $14.17 \pm 2.21$ & $15.44 \pm 2.15$ & $25.42 \pm 3.12$ & $80.22 \pm 2.24$ \\
\hline 7 & Control(Distilled water) & 0 & 0 & 0 & 0 \\
\hline$(P<0.001)$
\end{tabular}

To determine the sublethal effects of $20 \%$ methanol leaf extracts among all the plants estimations of biochemical constituents in the midgut of carpenter ants studied after each interval of 24, 48 and 72 hours of treatment (Table-2, 3 and 4). The biochemical composition of total protein, carbohydrate and lipid in the midgut of experimental set of carpenter ants shows significant decreasing concentrations as compared to control group (Figure 1, 2 and 3).

Table 2. Effect of $20 \%$ Methanolic Leaves Extract on the Biochemical composition of Midgut of the carpenter ant, Camponotus compressus after 24 hours (Exp.-Experimental group of ants)

\begin{tabular}{|c|c|c|c|c|c|c|c|}
\hline \multirow{2}{*}{ S. No.. } & \multirow{2}{*}{$\begin{array}{c}\text { Leaves Extract of } \\
\text { Plants }\end{array}$} & \multicolumn{4}{|c|}{ Biochemical Composition in $\mu \mathrm{g} / \mathrm{mg}}$, \\
\cline { 3 - 8 } & & \multicolumn{2}{|c|}{ Protein } & \multicolumn{2}{c|}{ Carbohydrate } & \multicolumn{3}{c|}{ Lipid } \\
\cline { 3 - 8 } & & Exp. & Control & Exp. & Control & Exp. & Control \\
\hline 1 & Pongamia glabra & $3.25 \pm 0.05$ & $6.76 \pm 0.02$ & $7.41 \pm 0.023$ & $10.4 \pm 0.015$ & $0.66 \pm 0.027$ & $1.25 \pm 0.027$ \\
\hline 2 & Tridax procumbens & $3.14 \pm 0.12$ & $6.62 \pm 0.055$ & $6.16 \pm 0.42$ & $10.15 \pm 0.11$ & $0.52 \pm 0.043$ & $1.35 \pm 0.056$ \\
\hline 3 & Azadirachta indica & $2.83 \pm 0.13$ & $7.01 \pm 0.23$ & $4.25 \pm 0.03$ & $10.5 \pm 0.33$ & $0.41 \pm 0.018$ & $1.15 \pm 0.06$ \\
\hline 4 & Vitex negundo & $2.23 \pm 0.03$ & $6.21 \pm 0.32$ & $3.35 \pm 0.21$ & $10.25 \pm 0.74$ & $0.31 \pm 0.03$ & $1.1 \pm 0.05$ \\
\hline 5 & Ipomoea carnea & $1.83 \pm 0.95$ & $6.51 \pm 0.88$ & $1.35 \pm 0.85$ & $10.15 \pm 0.94$ & $0.24 \pm 0.74$ & $1.25 \pm 0.82$ \\
\hline
\end{tabular}

$(\mathrm{P}<0.001)$

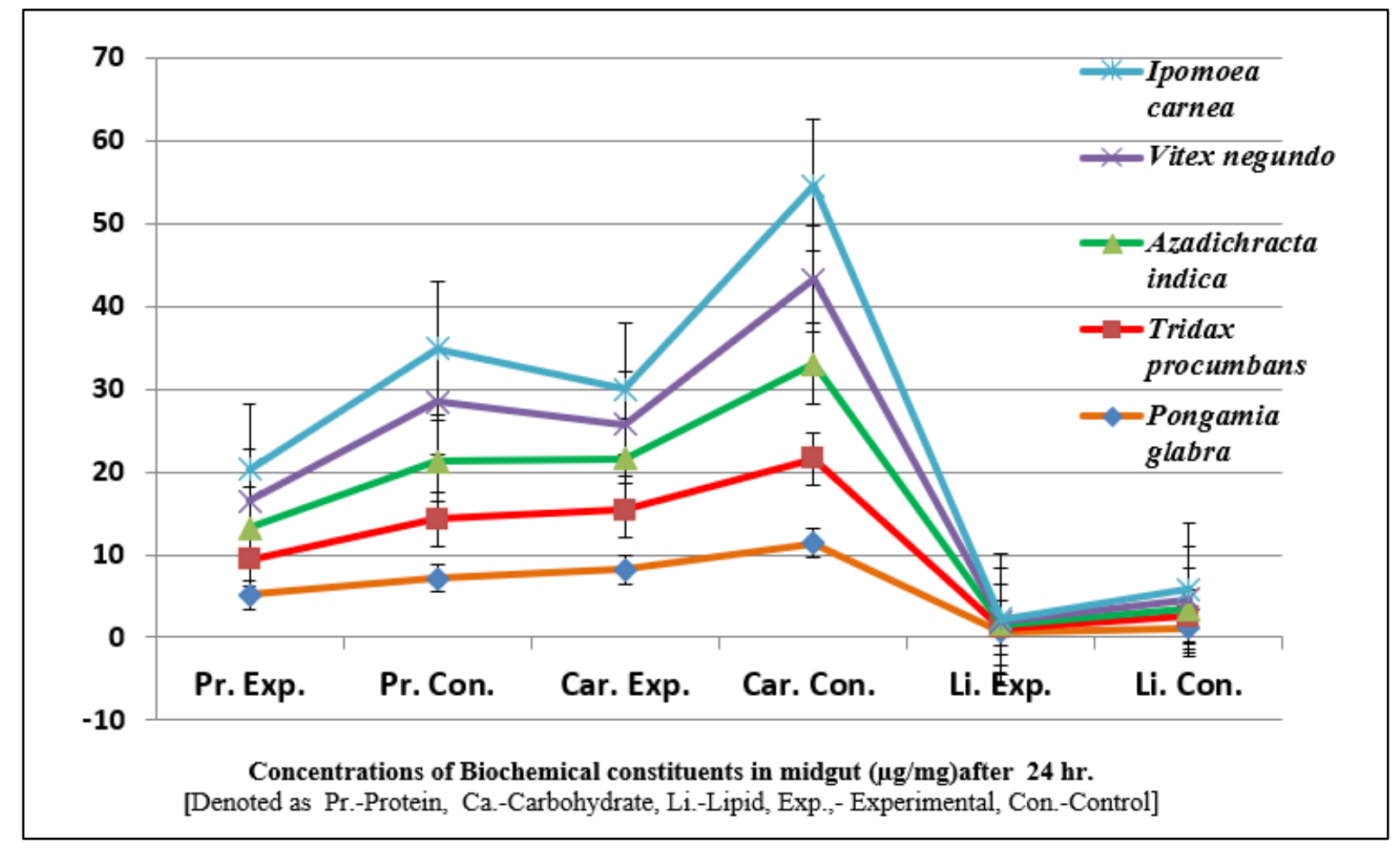

Figure 1. Effect of 20\% Methanolic Leaves Extract on the biochemical composition of midgut after 24 hours 
Table 3. Effect of $20 \%$ Methanolic Leaves Extract on the Biochemical composition of Midgut of the carpenter ant, Camponotus compressus after 48 hours (Exp.-Experimental group of ants)

\begin{tabular}{|c|c|c|c|c|c|c|c|}
\hline \multirow{2}{*}{ S. No. } & \multirow{2}{*}{$\begin{array}{c}\text { Leaves Extract of } \\
\text { Plants }\end{array}$} & \multicolumn{2}{|c|}{ Biochemical Composition in $\mu \mathrm{g} / \mathrm{mg}}$, \\
\cline { 3 - 8 } & & \multicolumn{2}{|c|}{ Protein } & \multicolumn{2}{|c|}{ Carbohydrate } & \multicolumn{2}{c|}{ Lipid } \\
\cline { 3 - 8 } & & Exp. & Control & Exp. & Control & \multicolumn{2}{c|}{ Exp. } \\
\hline 1 & Pongamia glabra & $5.12 \pm 0.015$ & $7.16 \pm 0.012$ & $8.2 \pm 0.05$ & $11.4 \pm 0.6$ & $0.65 \pm 0.03$ & $1.15 \pm 0.014$ \\
\hline 2 & Tridax procumbens & $4.24 \pm 0.15$ & $7.12 \pm 0.05$ & $7.1 \pm 0.03$ & $10.1 \pm 0.2$ & $0.51 \pm 0.02$ & $0.4 \pm 0.02$ \\
\hline 3 & Azadirachta indica & $3.83 \pm 0.22$ & $7.01 \pm 0.26$ & $6.25 \pm 0.7$ & $11.4 \pm 1.25$ & $0.925 \pm 0.7$ \\
\hline 4 & Vitex negundo & $3.23 \pm 0.12$ & $7.11 \pm 2.27$ & $4.1 \pm 1.21$ & $10.2 \pm 3.17$ & $0.32 \pm 0.04$ & $1.15 \pm 0.01$ \\
\hline 5 & Ipomoea carnea & $3.83 \pm 0.58$ & $6.51 \pm 1.22$ & $4.2 \pm 1.21$ & $11.3 \pm 3.16$ & $0.33 \pm 0.03$ & $1.21 \pm 0.017$ \\
\hline
\end{tabular}

$(\mathrm{P}<0.001)$

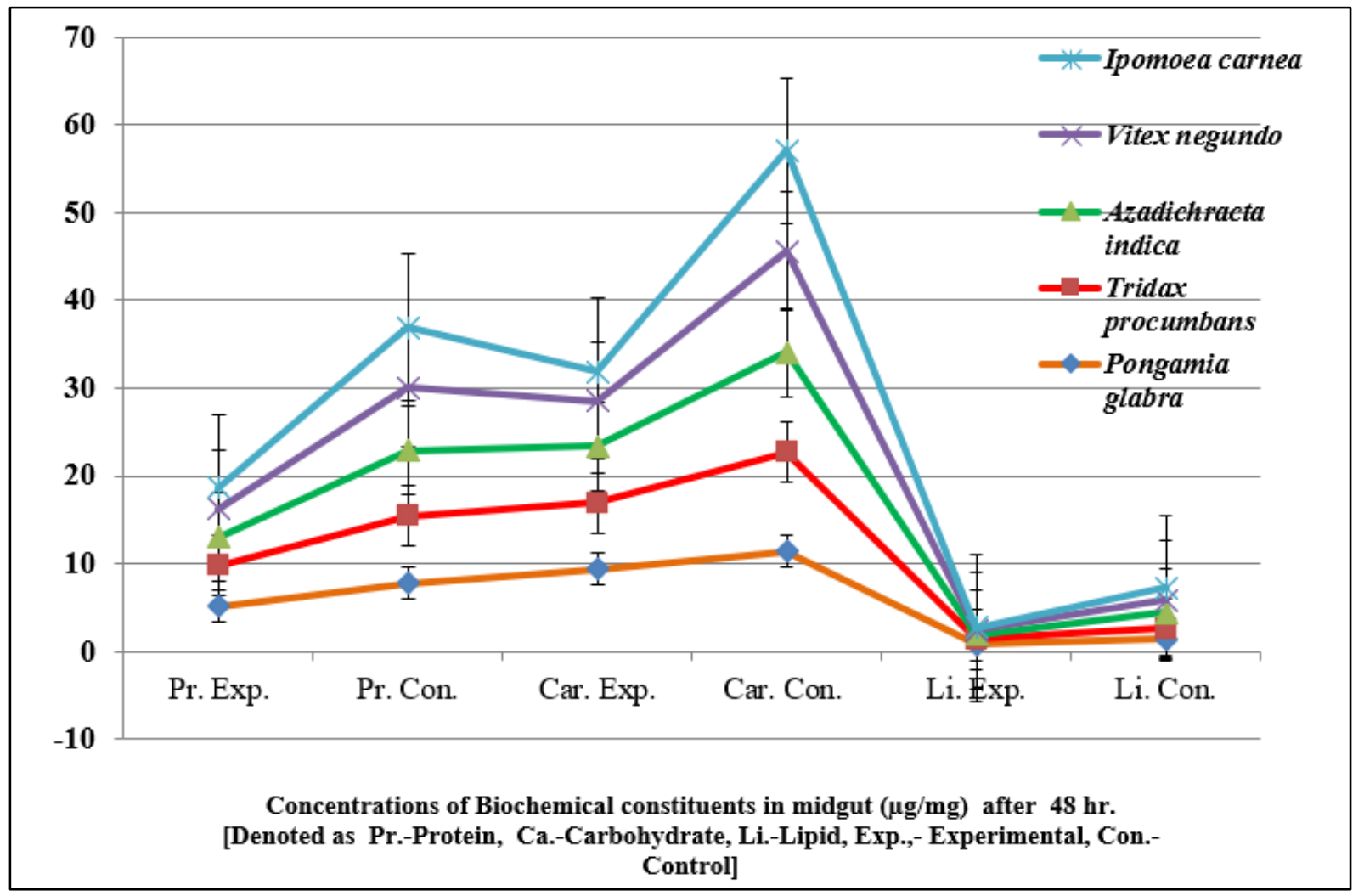

Figure 2. Effect of $20 \%$ Methanolic Leaves Extract on the biochemical composition of Midgut after 48 hours.

Table 4. Effect of $20 \%$ Methanolic Leaves Extract on the Biochemical composition of Midgut of the carpenter ant, Camponotus compressus after 72 hours. (Exp.-Experimental group of ants)

\begin{tabular}{|c|c|c|c|c|c|c|c|}
\hline \multirow{3}{*}{ S. No. } & \multirow{3}{*}{$\begin{array}{c}\text { Leaves Extract of } \\
\text { Plants }\end{array}$} & \multicolumn{6}{|c|}{ Biochemical Composition in $\mu \mathrm{g} / \mathrm{mg}$, } \\
\hline & & \multicolumn{2}{|c|}{ Protein } & \multicolumn{2}{|c|}{ Carbohydrate } & \multicolumn{2}{|c|}{ Lipid } \\
\hline & & Exp. & Control & Exp. & Control & Exp. & Control \\
\hline 1 & Pongamia glabra & $5.5 \pm 0.15$ & $7.76 \pm 0.17$ & $9.41 \pm 0.125$ & $11.4 \pm 0.06$ & $0.75 \pm 0.05$ & $1.35 \pm 0.007$ \\
\hline 2 & Tridax procumbens & $4.6 \pm 0.12$ & $7.62 \pm 0.28$ & $7.56 \pm 0.12$ & $11.2 \pm 0.05$ & $0.622 \pm 0.06$ & $1.25 \pm 0.05$ \\
\hline 3 & Azadirachta indica & $3.8 \pm 0.11$ & $7.51 \pm 0.27$ & $6.45 \pm 0.18$ & $11.4 \pm 0.04$ & $0.54 \pm 0.02$ & $1.78 \pm 0.03$ \\
\hline 4 & Vitex negundo & $3.2 \pm 0.41$ & $7.21 \pm 0.19$ & $5.15 \pm 0.18$ & $11.5 \pm 0.04$ & $0.44 \pm 0.02$ & $1.5 \pm 0.02$ \\
\hline 5 & Ipomoea carnea & $2.4 \pm 0.11$ & $6.85 \pm 0.14$ & $3.35 \pm 0.17$ & $11.45 \pm 0.03$ & $0.32 \pm 0.12$ & $1.35 \pm 0.021$ \\
\hline
\end{tabular}

$(\mathrm{P}<0.001)$ 


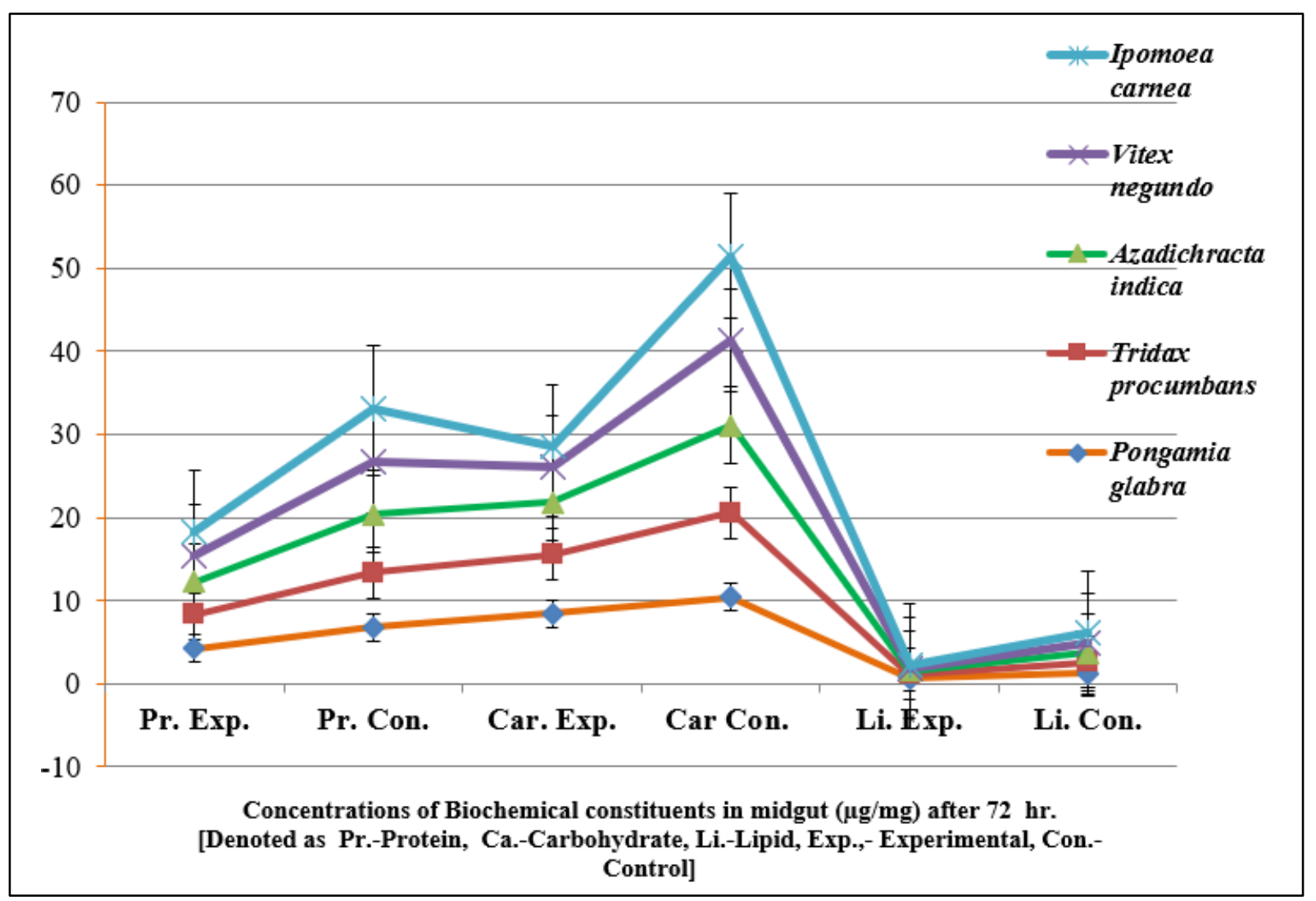

Figure 3. Effect of $20 \%$ Methanolic Leaves Extract on the biochemical composition of Midgut after 72 hours

Table 5. Effects of $20 \%$ Methanol Leaves Extract of Ipomoea carnea on the cellular structure in the midgut of adult carpenter ant, Camponotus compressus after 72 hours

\begin{tabular}{|c|c|c|c|c|c|c|c|}
\hline \multirow{3}{*}{ S.No. } & \multirow{3}{*}{$\begin{array}{l}\text { Time Interval } \\
\text { in Hours }\end{array}$} & \multicolumn{4}{|c|}{ Size of Columnar cells } & \multirow{2}{*}{\multicolumn{2}{|c|}{ Diameter of Nuclei $(\mu \mathrm{m})$}} \\
\hline & & \multicolumn{2}{|c|}{ Length $(\mu \mathrm{m})$} & \multicolumn{2}{|c|}{ Width $(\mu \mathrm{m})$} & & \\
\hline & & Exp. & Control & Exp. & Control & Exp. & Control \\
\hline 1 & 24 & $135.4 \pm 12.5$ & $124 \pm 24.5$ & $34.35 \pm 15.6$ & $39.5 \pm 16.4$ & $7.15 \pm 21.3$ & $8.22 \pm 32.5$ \\
\hline 2 & 48 & $145.4 \pm 24.2$ & $123.1 \pm 26.1$ & $31.2 \pm 31.5$ & $40.15 \pm 22.8$ & $5.43 \pm 18.4$ & $8.15 \pm 27.5$ \\
\hline 3 & 72 & $152.2 \pm 32.5$ & $122.5 \pm 41.5$ & $28.65 \pm 32.8$ & $40.5 \pm 46.2$ & $3.5 \pm 38.5$ & $8.25 \pm 42.4$ \\
\hline
\end{tabular}

The present study focused on the utmost lethal effects on the histopathology of midgut caused by the $20 \%$ methanolic leaf extracts of Ipomoea carnea treated as the stomach poison against the carpenter ant, Camponotus compressus. The histological study during the treatment of $20 \%$ methanol leaf extract of Ipomoea carnea showed maximum impairment of midgut cytological content and alterations in columnar cell size. The columnar epithelial cells in the midgut were observed elongated with increased length and decreased width (Table 5). The size of nucleus was observed decreased in diameter located towards the lumen with reduction of chromatin material due to lysis within the nuclei. The treatment of the methanol leaf extracts of Ipomoea carnea after the interval of 24, 48 and 72 hours causes cellular vacuolization with extreme damages to the epithelial cells and nuclear material. These results were predominantly appeared as the sublethal effects like the highly persuasive insecticide (Table 5 and Figure 4). 


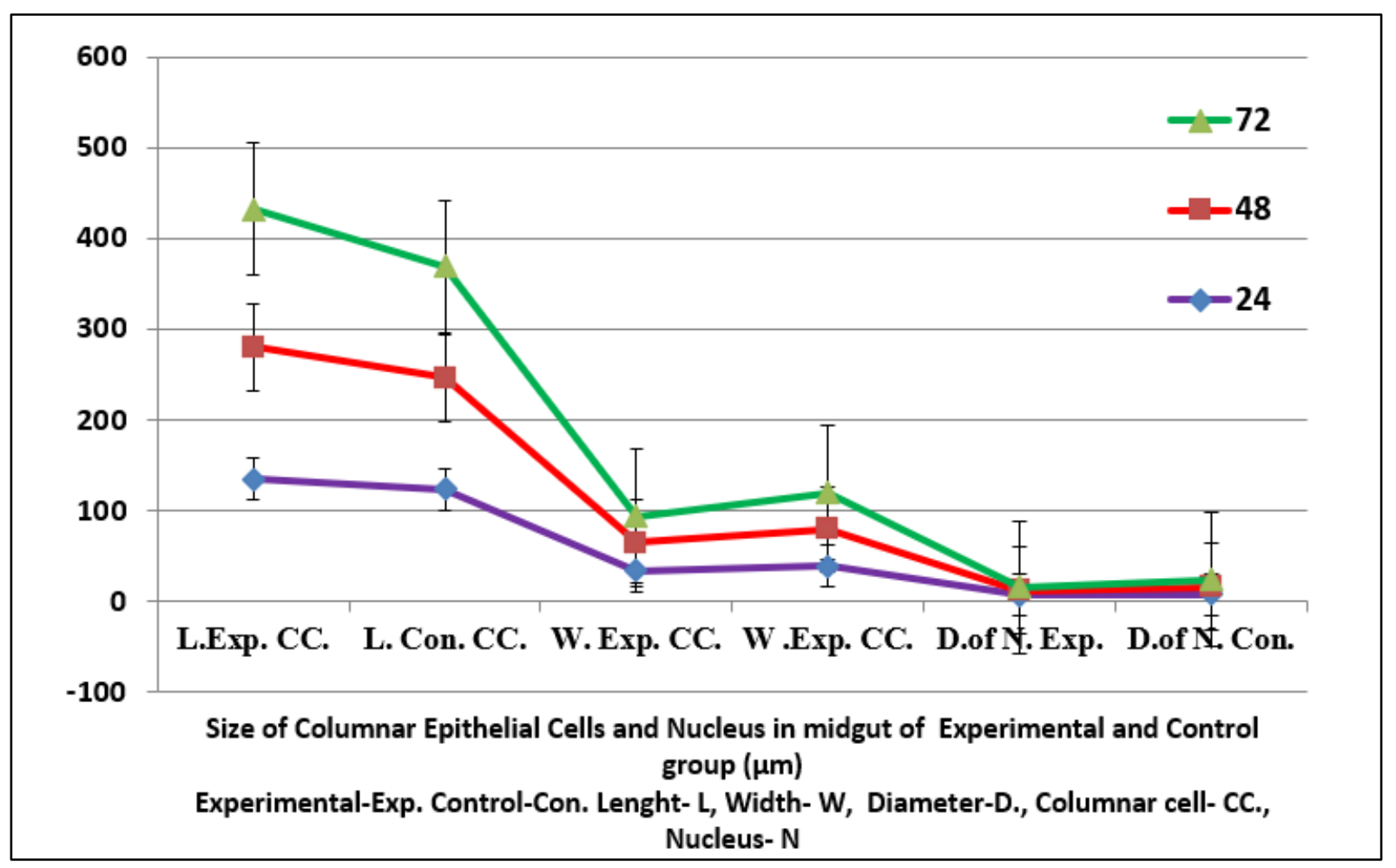

Figure 4. Effect of $20 \%$ Methanol Leaves Extract of Ipomoea carnea on the cellular structure in the midgut of adult carpenter ant, Camponotus compressus after 72 hours

The present study revealed the significant alterations in biochemical composition and histology of the midgut in carpenter ants. The midgut is the important as an organ therefore any such cellular alterations may lead to disturbances in insect's physiology and behavior. The aim of present study was to examine whether of exposure of leaf extracts of some indigenous plants correlates with the insect mortality and ultra-structural parameters in adult stages of the carpenter ants.

From the results obtained during the present study it becomes quite apparent that the $20 \%$ methanol leaves extract of the locally available plant, Ipomoea carnea showed the highest sublethal toxicity and can be considered as the most competent herbal insecticide against the carpenter ant, Camponutus compressus followed by the plants, Vitex negundo, Azadirachta indica, Tridax procumbans and Pongamia glabra respectively.

\section{Discussion and Conclusion}

The carpenter ant, Camponotus compressus along with some other ants, form a group of household insect pests causing consistent nuisance and damaging store grains, food materials, bakery products, sweets and ornamental as well as vegetable plants [14,15]. Ant behavior depends upon a number of environmental conditions one of which is the availability of different food resources. In general by applying an ant bait consisting boric acid at variable concentrations used to control the developmental stages of household ants and colony population. The treatment of these oral toxins distributed among the nest mates and larvae through regurgitation during trophyllaxis $[19,5,6]$. Such synthetic insecticides give maximum mortality by exerting nervous, digestive and respiratory toxin [16,24]. These substances are, moreover found to be inducing high mortality of chicks and poisoning food and bakery products [1,10]. Riemann and Flint [26] noticed lethal effects on the boll weevils, Anthonomous grandis due to the loss of midgut epithelial cells and regenerative cells caused by insecticides. The Annona seed extracts effects on the reduction of total protein content influencing adversely the protein metabolism and the vital process in insect life [3]. Derivatives of local plants such as kernel powder and seed oils of Azadirachta indica [29] were also reported to be effective against coleopteran pests due to their antifeedant, ovicidal, insecticidal and other growth regulatory actions. In the carpenter ant, Camponotus compressus the midgut is lined with enteric epithelium with thin peritrophic membrane as the innermost layer. It is the main site for the synthesis of different enzymes and biochemical components that carry out the digestion and metabolism similar to hymenopteran bees [34]. The histopathological studies on midgut of carpenter ant resulted in degradation of the basal membrane and degeneration in the epithelial lining after the treatment of $20 \%$ methanol leaf extracts of the plant, Ipomoea carnea. These observations were almost similar to that reported in 
Hieroglyphus nigrorepletus [27], Heliothis herrata [21] and in Periplaneta Americana [31] after the treatment some synthetic insecticides. So the mode of action of the leaf extracts may be directly effects on the histopathology and physiology of midgut of the carpenter ant acting as a sublethal concentration within exposed populations.

The present study determined the action and sublethal concentration of leaf extracts of Ipomoea carnea extracts as the potent insecticide directly affected on biochemical constituents such as total proteins, carbohydrates and lipids. This is the first study suggesting sublethal effects of the $20 \%$ formulations of leaf extracts of locally available indigenous plants on digestion, absorption and metabolism ultimately leading to death of the ants. It becomes apparent that these insecticidal effects of the plant extracts are exerted due to the action of toxic substances like alkaloids and enzymes as discussed above. Therefore this study revealed the effective use and broad spectrum mode of action of botanical insecticides as the stomach and contact insecticides exercises knock down effects in future and reduces the use of synthetic insecticides.

\section{REFERENCES}

[1] Alley, E. G. The use of mirex in the control of imported fire ant. J. of Environ. Quality. 2(1): 52-61. Amer. 60: 298-308, 1973.

[2] Amrithraj, M. P. And William, J. The efficacy of two botanicals as repellants against Monomorium pharaonis (Hymenoptera: Formicidae) in biopesticide in insect pest management, (ed. By- Ignacimuthu and Sen), Phonex Publ. House Pvt. Lt. New Delhi. 144-151,1999.

[3] Boreddy, Y., Chitra, K. C. And Eswar Reddy, N. P. Studies on sublethal concentration (LC30) of Annona Seed Extract on total proteins of Spodoptera litura (Fab.) Ento. 25(4): 351-355, 2000.

[4] Cutler, M. Secondary metabolites from plant and their allelochemicals, effect $\mathrm{s}$ in Bioregulators for pest control. Amer. Chem. Soc., 225-236, 1985.

[5] Davidson, D. W. Elemental stoichiometry of ants in a new world rain forest. Oeologia., 142: 221- 231, 2005.

[6] Dejean, A., Mckay, D., Giberhau, M., And Berlin, M. The arboreal ant mosaic in a Cameronian rainforest (Hymenoptera: Formicidae). Sociobio. 35: 403- 23, 2000.

[7] Dubois, M., Gilles, K. A., Hamilton, J. K., Rebers, R. A. And Smith, F. (Annl. Chem. 28: 350, 1956).

[8] Frings, C. S. And Dunn, R. T. Amr. J. Clin. Path. 3: 89-91, 1970.

[9] Garrett, H. Herbs for Texas: a study of the landscape, culinary, and medicinal uses and benefits of herbs that can be grown in Texas. University of Texas Press, Austin, 242 pp. 2001.
[10] Hill, D. K., Hall, E. I. , Sander, J. E., Fletcher O. J., Page, R. K., Davis, S. W., Diazinon toxicity in broilers Avian diseases. 38 (2): 393- 396, 1994

[11] Haraguchi, M., Gomiak. S. L., Ikeda, K., Miami, Y., Kato, A., Kato, A., Watson, A. W., Nash, R. J., Molyneux, R. J. and Asano, N. Alkalloidal Components in the Poisonous Plant, Ipomoea carnea (Convolvulaceae). J. Agric. Food Chem., 51 (17): 4998- 5000, 2003.

[12] Humason, G. L. Animal Tissue Technique W. H. Freeman and Company, San Francisco and London, 1962.

[13] Isman M.B., Botanical insecticides, deterrents, and repellents in modern agriculture and an increasingly regulated world. Annual Review of Entomology, 51; pp. 45-66, 2006.

[14] Kadu, S. G., Tembhare, D. B., Barsagade, D. D., Efficasy of Botanical extracts against the household pest, carpenter ant Camponoutus compreessus(Fabricius), J. Soil and Crops 20(2) 314-317, 2010.

[15] Kadu, S. G. and Kulat, S. S. (2015). Control of household pest red imported fire ant, Solenopsis invicta Buren (Hymenoptera: Formicidae) Using Herbal Extracts. IJRBAT, Special Issue A-3: pp-187-191.

[16] Lee, S., Peterson C.J., Coats, J.R., Fumigation toxicity of monoterpenoids to several stored product insects. Journal of Stored Products Research, 39 ; pp. 77-85, 2003.

[17] Longino, J. T. The Creamtogaster of Coast Rica. Zootaxa 151. 0 -151, 2003.

[18] Lowery, L. H., Rosebrought, A. L. And Randall, R. J. Protein Measurement with folin- phenol reagent. J. Biol. Chem., 93: 65- 75, 1951.

[19] Maillux, A. C., Jeans-Louis, D. And Detrain, C. How do ants assess food volume? Anim. Behav. 59: 1061- 1069, 2000.

[20] Nawrot J., Harmatha J., Natural products as antifeedants against stored product insects. Post Harvest News and Information, 5; pp. 17N-21N, 1994.

[21] Patil, S. B., Wagh, S. R., Nikam, S. D. And Bhawane, G. P. Effect of Insecticide on the midgut of $\mathrm{H}$. serrata Fab. (Coleoptera: Scarabaedae). Ind. J. of Comp. Animal Physio., Vol. 21. pp. 20-23, 2003.

[22] Patel, A. K., Singh, V. K., Jagannadham, M. V. Carnein a serine protease from noxious plant weed Ipomoea carnea. Varanasi. J. Agric. Food Chem., 2007.

[23] Parveen, Z. and Masud, S. Z. Organochlorine pesticide residues in cattle drinking water. Pak. J.Sci. Ind. Res., 31: 53-56. 1988B

[24] Peterson C. J., R. Tsao, J.R., Naturally occurring cyanohydrins, analogues and derivatives as potential insecticides. Pest Management Science, 56; pp. 615-61, 2000.

[25] Rahalkar, G. W., Dongre, T. K. And Tamhankar, A. G. Proc. Int, Conf. Natural Products as Regulators of Ins, Reprdn. RRL, Jammu Abstracts: 17, 1983.

[26] Riemann, J. G., Flint, H. M. Irradiation effects on midguts and tests of the adult boll weevil, Anthonomous grandis, determined by histological and shielding studies. Ann. 
Entomol. Soc. Amer. 60: 298-308, 1967.

[27] Rizvi, S. S. A. And Khan, M.A. Observation on pathological effects of certain stomach poisons on the histology of the midgut and caecae of third instar hoppers of (Hieroglyphus nigroreplitus Boliver) (Orthoptera: Acrididae). Ind. J. Zool. 2: B: 7-94, 1973.

[28] Schatz, Bertrand, and Martine Hossaert-Mckey. "Interactions of the Ant Crematogaster scutellaris with the Fig/fig Wasp Mutualism." Ecological Entomology 28, 3: 359-68, 2003.

[29] Shafeek, A., Rachelkumari, M., Nagaraja, S. And Rajarami Reddy, G. Alterations in moulting pattern and protein levels in Grasshopper, Piocelocerus pictus, exposes to synthetic prethroid, Cypermethrin. Ind. J. Comp. Anim. Physio. Vol. 16: 38- 45,1998.

[30] Singh, B. P. And Singh, S. Evaluation of deoiled neem,
(Azadirachta indica a. Juss.) seed kernel against Trogoderma granarium Ever.,Cur. Scie. 54(18): 959-951, 1985.

[31] Sunanda Majumdar, Mohammad Amir, Ritika Gupta and Shagufta Yasmeen. Histopathological effect of deltamethrin on the midgut of American cockroach, Periplaneta americana (Linn.) (Dictyoptera: Blattidae). Jou. Ent. and Zoo. Studies, 4(5): pp13-16, 2016.

[32] Tripathi A. K., Prajapati V., Kumar S. Bioactivities of l-carvone, d-carvone, and dihydrocarvone toward three stored product beetles. Journal of Economic Entomology, 96; pp. 1594-1601, 2003.

[33] Ware, G. W., The pesticide book, 5th ed. Thomson Publications, Fresno, California. 415 pp. 2000.

[34] Wigglesworth, V. B. (). The Principle of Insect Physiology. I. 741. Methecen, London, 1977. 